\title{
A PERCEPÇÃO DA PAISAGEM: 0 CASO DO RIO CARAHÁ NO CONTEXTO URBANO DE LAGES, SC
}

\section{FERNANDA CAROLINE GUASSELLI, M.SC. | UFSC VANESSA CASARIN, Dra. |UFSC}

\section{RESUMO}

Os paradigmas ambientais contemporâneos vêm transformando os modelos de planejamento urbano ambiental, especialmente o tratamento dado aos corpos d'água e suas bordas: promovendo a recuperação dos rios, tornando suas margens espaços multifuncionais e vetores de urbanidade que contribuem para a qualidade de vida nas cidades. Apesar dos avanços recentes, estudos demonstram que esses novos modelos ainda possuem desafios e lacunas a serem estudadas, como a relação entre qualidade ecológica e estética que se apresenta dicotômica no âmbito das pesquisas em percepção ambiental, além da integração entre as funções ambientais e urbanas, importante debate no contexto brasileiro que possui tal problemática associada a sua legislação ambiental. Nesse sentido, a fim de compreender essas questões e contribuir com esses novos modelos, o presente estudo investigou as percepções e preferências visuais atreladas à paisagem do rio Carahá, em Lages/SC, através de uma abordagem multimétodo sob o aporte teórico da percepção ambiental. Os objetivos específicos da pesquisa envolveram; (I) Identificar a imagem ambiental (individual e coletiva) associada ao rio; (II) Examinar as relações afetivas dos habitantes para com o rio e a influência do afeto na construção das imagens cognitivas; (III) Expressar a preferência visual dos habitantes em relação às possíveis configurações das margens do rio. Para tanto, realizou-se pesquisa documental, entrevista semiestruturada com os moradores do entorno do Rio Carahá $(n=53)$ e um fotoquestionário com os moradores da cidade de Lages $(n=320)$. Os dados qualitativos foram submetidos à análise de conteúdo, enquanto os dados quantitativos foram analisados através de estatística descritiva e do teste Chiquadrado de Pearson. Os principais resultados referem-se à classificação e categorização das múltiplas imagens ambientais associadas ao rio, bem como sua imagem coletiva (lixo/sujeira) e idealizações para seu futuro (despoluição). Com isso, examinou-se que o afeto está intrinsecamente relacionado à construção das imagens cognitivas, pois os relatos apontaram para o sentimento de aversão ao rio devido à poluição e inundações. Por fim, na etapa do fotoquestionário através da seleção dos cenários de maior e menor preferência, observou-se que os respondentes desejam a integração entre ambiente natural e construído (Figura 1), rejeitando a hipótese de uma paisagem totalmente artificializada (Figura 2). Nessa mesma linha, o teste Chi-quadrado de Pearson indicou que existe dependência ( $p$-valor $<0,05)$ entre nível de naturalidade das margens e lazer e recreação passiva, corroborando o debate teórico sobre o caráter multifuncional das margens dos rios urbanos. Diante do exposto, considerando que os estudos de percepção ambiental transformam dados subjetivos em instrumentos objetivos à arquitetura e urbanismo, os resultados obtidos contribuem para o planejamento e desenho das margens dos rios urbanos através da premissa de integração entre as funções ambientais e urbanas, qualidade ecológica e estética. Já na escala do estudo de caso, as temáticas extraídas das entrevistas são potencialmente uma lista de prioridades aos gestores públicos municipais em prol da recuperação do Rio Carahá, ressignificando sua imagem negativa perante à população e motivando a afeição pelo lugar.

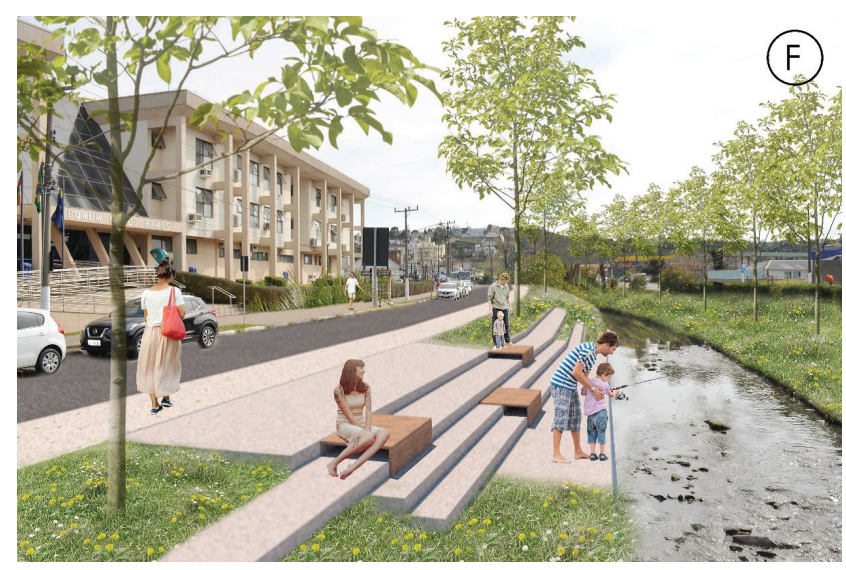

Figura 1: Cenário de maior preferência para o tratamento de bordas de rios urbanos entre os respondentes.

Fonte: Guasselli, F. C. 2020. 


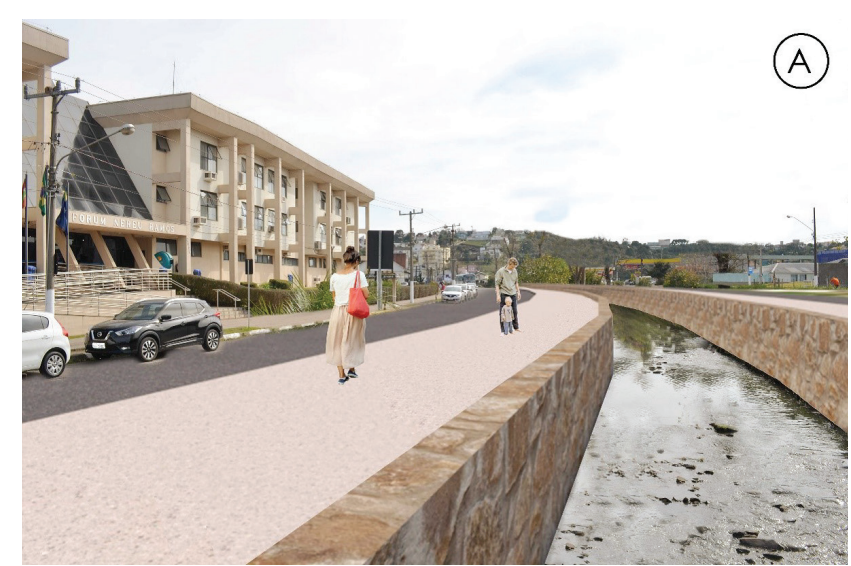

Figura 2: Cenário com maior rejeição entre os respondentes para o tratamento de bordas de rios urbanos.

Fonte: Guasselli, F.C. 2020.

\section{REFERÊNCIA}

GUASSELLI, F. C. A percepção da paisagem: O caso do Rio Carahá no contexto urbano de Lages, SC. Dissertação (mestrado) - Universidade Federal de Santa Catarina, Centro Tecnológico, Programa de PósGraduação em Arquitetura e Urbanismo, Florianópolis, 2020. Disponível em: https://repositorio.ufsc.br/handle/123456789/216142. Acesso em: 13/11/2020. 